\title{
Giving the Authority to Subordinates: Does Budget Participation Really Affect Budgetary Slack in Public Sector?
}

\author{
Made Aristia Prayudi ${ }^{1, *}$ Nyoman Suadnyana Pasek ${ }^{2}$ I Gede Agus Pertama \\ Yudantara $^{2}$ \\ ${ }^{1}$ Doctoral Program in Accounting, Universitas Brawijaya, Malang, Indonesia \\ ${ }^{2}$ Department of Economics and Accounting, Universitas Pendidikan Ganesha, Singaraja, Indonesia \\ *Corresponding author.Email: prayudi88@student.ub.ac.id
}

\begin{abstract}
Although budget participation is acknowledged as a budgeting system that allows subordinates and superiors to create a more realistic budget and hinder budgetary slack, it is still unclear what mechanism in this process plays the role. This study focuses on the fairness perception of subordinates concerning the right to voice and vote in the budgeting process. This study aims at investigating the effect of budget authority on budgetary slack in the public sector. Data were collected by conducting an experimental study with 98 final-years undergraduate accounting students of a large public university in Bali. Using the One-Way ANOVA test as a data analysis technique, the type of budget authority does affect the creation of budgetary slack. The condition of superior budget authority (voice but no vote) encourages slacker than when the subordinate holds the authority (voice and vote). The results have some implications for organizational management policies.
\end{abstract}

Keywords: Budget Authority, Budget Participation, Budgetary Slack, Public Sector Accounting.

\section{INTRODUCTION}

\subsection{Research Background}

Budgetary participation is a budgeting system that allows subordinates and superiors to be actively involved in reviewing the budget, ratifying the budget, and monitoring the results of budget implementation to create a realistic budget. Through the active participation of subordinates, the budget can be prepared more rationally to be realized. On the other hand, active participation from superiors is also essential because, without it, subordinates will tend to set a budget that is relatively easy to achieve [1]. This is known as budgetary slack or budget slack. Budgetary slack is defined as overstated expenses, i.e., intentionally overstated expenses, and understated revenues, i.e., revenues that are intentionally understated or underestimated performance capabilities, i.e., performance capabilities that are deliberately lowered [2].
Budgetary slack is an issue of ethical and moral behavior in the form of inefficiency and ineffectiveness of resource use, resulting in losses in the organizational budget structure. Budget slack is believed to be more likely to occur in public organizations due to the characteristics of the budgeting process and its rigid bureaucracy. It does not allow transfers between budget posts or additional funding during the budget period. Consequently, at the formulation stage, the management will propose a budget that is higher than the actual need to create an operational buffer fund.

This study focuses on the fairness perception of subordinates concerning the right to voice and vote in the budgeting process. This study aims at investigating the effect of budget authority on budgetary slack in the public sector. Perceptions of fairness were found to direct individuals not to act fraudulently and unethically even when there is motivation and opportunity [3], [4]. In the context of participatory budgeting, subordinates' perceptions of justice can focus on justice in the process (procedural justice) and justice in results (distributive 
justice) [5]. In general, when subordinates perceive these aspects of justice as being fulfilled, the honesty characters in themselves will also be stimulated and underlie their decision-making [6].

The term 'voice' refers to the opportunity that a person has to express their personal opinion in the standard/policy setting process [5]. Someone perceives that there is fairness in the process when the voice aspect is fulfilled. Meanwhile, 'vote' is the right to determine the standards/policies that are finally set. As with voice, vote ownership is also positively related to perceptions of fairness in the process.

Budget authority refers to a binary option to approve/reject a budget proposal without the ability to make a counteroffer to the proposed proposal [7]. In a participatory budgeting scheme, budgetary authority can be owned by either superiors or subordinates. The existence of budgetary authority in superiors represents the little voice of subordinates in the budgeting process. In contrast, being given final budget authority (subordinate authority) can reflect vote ownership for subordinates. Ref [5] argues that a vote demonstrates a higher level of control-over-process than voice, so vote ownership will also give a higher perception of fairness. Thus, subordinates who perceive that justice has been fulfilled in the budgeting process will make decisions more honestly [6] and, in the end, avoid creating budget slack.

Also, when the subordinate has the final authority to set the budget, the superior cannot reject the budget proposal given by the subordinate. This mechanism will trigger subordinates to frame the budgeting process as an ethical dilemma that can stimulate the emergence of honesty motivation or other non-financial motivations in subordinates [8]. Thus, the potential for budget slack will be minimized. On the other hand, subordinates will frame the budgeting process as a strategic interaction when superiors have budgetary authority. Each party, both superiors, and subordinates behaves in their interests. The motivation for honesty or other nonfinancial incentives in subordinates, therefore, will also be eroded, giving rise to the potential for creating higher budget slack. Thus, the hypothesis in this study is stated as follows:

$\mathrm{H}_{1}$ : Budgetary slack is more commonly found in subjects who are in a condition of superior authority than in subjects who are in a subordinate authority

\section{METHOD}

Data were collected by conducting an experimental study with 88 final-years undergraduate accounting students of a large public university in Bali. The manipulated factor (independent variable) is budgetary authority (authority to superiors (KA) versus authority to subordinates (KB). The data obtained in this study were analyzed using the statistical technique One-Way Analysis of Variance (ANOVA) in order to determine the difference in the mean values in two sample groups [9].

The variable of budgetary authority is conditioned into two categories, namely the type of budgetary authority to superiors and the type of budgetary authority to subordinates. In the condition of the supervisor's type of authority, the amount of the final proposed budget will be reviewed by the superior and the amount actually reported to the Head of the UPT is fully under the authority of the superior. Meanwhile, under the conditions of the type of subordinate authority, the amount of the final proposed budget will not be reviewed by superiors and the amount actually reported to the Head of the UPT is fully under the authority of the subordinates. The budgetary slack is measured based on the amount of budget slack value created, namely the difference between the initial proposed budget value and the final budget value proposed by the participants.

The experimental task used in general adapts Davis et.al [10] with adjustments to grammatical aspects, context of cases in the organizational environment in Indonesia and the translation of several case narratives into the form of real treatment to participants. In general, participants are conditioned in setting a role as finance staff of a division within the technical implementing unit (UPT) organization that plays a central role in a university. Participants are assigned the task of submitting an operational cost budget for the next one-year period. There is a general policy from the Head of UPT that related to the condition of the university's budget which is being tightened, the amount of the budget proposed by all divisions in UPT is made as accurate as possible, namely the amount of the budget should describe the amount of expenditure that can be achieved by each division in the coming year.

Participants were then given historical data on the comparison of the division's realization and budget for the last four years (2016-2019) with an average efficiency trend (budget and realization) of $10 \%$. Participants were also given hypothetical financial data in the form of estimated costs that are predicted to be real in 2021, which are IDR 45,000,000.00. Based on this data, participants were instructed to submit the budget amount online through a computerized budget submission application.

\section{RESULTS AND DISCUSSION}

\subsection{Descriptive Statistical Analysis of Participant Demographics}

Of the 98 participants, $54(65.31 \%)$ were female and $44(34.69 \%)$ were male. The average age of the 
participants was 20.77 years with an age distribution of 20 years as many as 38 people $(38.77 \%)$; age 21 years as many as 45 people $(45.92 \%)$ and age 22 years as many as 15 people $(15.31 \%)$.

\subsection{Hypothesis Testing}

The hypothesis predicts the influence of the type of budgetary authority on the behavior of creating budget slack, namely that budget slack behavior is more commonly found in subjects who are in a condition of 'superior authority' compared to subjects who are in a condition of 'subordinate authority'. The results of the One-way ANOVA test show that the value of budget slack in the group of participants who are in the 'superior authority' condition is greater (mean $=\mathrm{Rp}$. $33,451,346.53$ ) than in the group of participants who are in the 'subordinates authority condition' (mean $=\mathrm{Rp}$ $25,731,863.55)$. This difference was significant at the significance level of $\mathrm{p}<0.01(\mathrm{~F}=16.324)$. Thus, it can be concluded that the hypothesis is supported by empirical data.

\subsection{Discussion}

This study succeeded in finding evidence of the role of the type of budgetary authority in determining the behavior of budget slack by subordinates. The granting of personal authority to subordinates (subordinate authority) is indicated to be able to give freedom to subordinates to submit a budget according to their personal preferences without the need to consider the strategic-economic consequences of their decision. Basically, the type of subordinate authority will indeed frame the budgeting process into an ethical dilemma, while the type of superior authority will direct the budgeting process as a strategic negotiation process [8]. Budgeting that goes through the negotiation process will allow subordinates to decide to create budget slack [11] because subordinates will utilize all the private information, they have to maximize the share of "profits" that can be obtained in the budget negotiation process [12]. The findings of this study are consistent with the research results of Brink et al [7].

\section{CONCLUSION}

This study aims at investigating the effect of budget authority on budgetary slack in the public sector. It is found that the type of budget authority does affect the creation of budgetary slack. More specifically, the ownership of final authority in subordinates (subordinate authority) was found to provide sufficient conditions to mitigate the emergence of budget slack behavior. This implies the potential usefulness of the budgeting mechanism that allows subordinates to determine the final proposed budget without an evaluation process from and negotiation with superiors.

This study has limitations in terms of the relatively low potential for generalization of results due to the natural characteristics of the use of laboratory experimental methods that favor internal validity over external validity [13]. The selection of final year Accounting students as a substitute and the creation of an artificial work environment is certainly not able to perfectly represent the real and natural conditions of the organization's budgeting process. This study, however, proved to be able to adequately control only certain factors that were thought to influence the creation of budget slack, namely the compliance pressure factor and the type of budget authority factor. Further research can implement field experiment research designs to obtain more generalizable results.

\section{REFERENCES}

[1] N. L. Srimuliani, L. S. Musmini, and N. T. Herawati, "Pengaruh Partisipasi Anggaran, komitmen organisasi, dan Job Relevant Information (JRI) terhadap Senjangan Anggaran Studi Empiris pada Satuan Kerja Perangkat Daerah di Kabupaten Buleleng)," JIMAT (Jurnal Ilm. Mhs. Akuntansi) Undiksha, vol. 2, no. 1, pp. 1-11, 2014.

[2] M. M. Mowen, D. R. Hansen, and D. L. Heitger, Cornerstones of Managerial Accounting - Google $B u k u, 6$ th ed. Cencage Learning, 2016.

[3] J. R. Cohen, L. Holder-Webb, D. J. Sharp, and L. W. Pant, "The Effects of Perceived Fairness on Opportunistic Behavior," Contemp. Account. Res., vol. 24, no. 4, pp. 1119-1138, 2007, doi: 10.1506/car.24.4.3.

[4] C. Daumoser, B. Hirsch, and M. Sohn, "Honesty in Budgeting: a Review of Morality and Control Aspects in the Budgetary Slack Literature," $J$. Manag. Control, vol. 29, no. 2, pp. 115-159, 2018, doi: 10.1007/s00187-018-0267-z.

[5] T. M. Lindquist, "Fairness as an Antecedent to Participative Budgeting: Examining the Effects of Distributive Justice, Procedural Justice and Referent Cognitions on Satisfaction and Performance," J. Manag. Account. Res., vol. 7, no. 1990, pp. 122-147, 1995, [Online]. Available: http://search.ebscohost.com/login.aspx?direct=true $\& \mathrm{db}=\mathrm{bth} \& \mathrm{AN}=9510062225 \&$ site $=$ ehost live $\&$ scope $=$ site.

[6] D. Rosdini, "Shared Financial Interest, Fairness, and Honesty in Budget Reporting: Experimental Study in Indonesia," Rev. Integr. Bus. Econ. Res., vol. 5, no. 3, pp. 266-282, 2017. 
[7] A. G. Brink, J. C. Coats, and F. W. Rankin, "Deceptive superiors and budgetary reporting: An experimental investigation," J. Manag. Account. Res., vol. 29, no. 3, pp. 79-91, Sep. 2017, doi: 10.2308/jmar-51591.

[8] F. W. Rankin, S. T. Schwartz, and R. A. Young, "The Effect of Honesty and Superior Authority on Budget Proposals," Account. Rev., vol. 83, no. 4, pp. 1083-1099, 2008, doi: 10.2308/accr.2008.83.4.1083.

[9] J. F. Hair, W. C. Black, B. J. Babin, and R. E. Anderson, Multivariate Data Analysis: A Global Perspective, 7th ed. New Jersey: Pearson Education, Inc., 2010.

[10] S. Davis, F. T. DeZoort, and L. S. Kopp, "The Effect of Obedience Pressure and Perceived Responsibility on Management Accountants' Creation of Budgetary Slack," Behav. Res. Account., vol. 18, pp. 19-35, 2006.

[11] M. C. Jensen and W. H. Meckling, "The Nature of Man," J. Appl. Corp. Financ., vol. 7, no. 2, pp. 419, 1994.

[12] Q.-H. Ngo, T.-N.-N. Doan, and T.-N. Huynh, "A Study on Managers' Creation of Budgetary Slack in Emerging Economies: The Case of Vietnam," Asian J. Account. Res., vol. 2, no. 2, pp. 15-28, 2017, doi: 10.1108/ajar-2017-02-02-b003.

[13] U. Sekaran, Research Methods for Business: A Skill-Building Approach, 4th ed. John Wiley \& Sons, Inc., 2011. 